\title{
ORIGINAL ARTICLE \\ From He-Cession to She-Stimulus? The labor market impact of fiscal policy across gender
}

\author{
Alica Ida Bonk ${ }^{1} \cdot$ Laure Simon $^{2}$ \\ Received: 11 February 2021 / Accepted: 8 June 2021 / Published online: 21 October 2021 \\ (c) The Author(s) 2021
}

\begin{abstract}
Men, especially those that are young and less educated, typically bear the brunt of recessions because of the stronger cyclicality of their employment and wages relative to women's. We study the extent to which fiscal policy may offset or worsen these asymmetric effects across gender. Using micro-level data for the U.S. from the Current Population Survey, we find that the effects of fiscal policy shocks on labor market outcomes depend on the type of public expenditure. Women benefit most from increases in the government wage bill, while men are the main beneficiaries of higher investment spending. Our analysis further reveals that the fiscal component most efficient at closing gender gaps is least suitable for offsetting inequitable business cycle effects across other socioeconomic dimensions.
\end{abstract}

Keywords Fiscal policy · Gender gaps · Heterogeneous labor market outcomes · Business cycles

\section{Introduction}

Despite substantial progress in the labor market fortunes of women over recent decades, gaps in wages and employment rates between male and female workers remain significant. In addition, gender differences in industry composition can gener\footnotetext{
views of the Swiss National Bank or the Bank of Canada.

$凶 \quad$ Laure Simon

1simon@bankofcanada.ca

Alica Ida Bonk

alicaida.bonk@snb.ch

1 Swiss National Bank, Börsenstrasse 15, 8001 Zurich, Switzerland

2 Bank of Canada, 234 Wellington Street, Ottawa, ON K1A 0G9, Canada
}

We are grateful to Evi Pappa, Leonardo Melosi, Axelle Ferriere, Juan Dolado and Alexandra Fotiou for their helpful comments. We also thank Dimitrios Bermperoglou for sharing his codes with us. The views in this paper are solely the responsibility of the authors and should not be interpreted as reflecting the 
ate cyclical fluctuations in labor market gaps, as men tend to be employed in sectors more exposed to business cycles. ${ }^{1}$ Notably, young, less-educated and blue-collar men are particularly strongly affected. ${ }^{2}$ The role of fiscal policies in reducing inequalities has recently received increasing interest in the literature, with less attention paid to the gender dimension. Evaluating the ability of government spending to address both policy goals, i.e., to reduce inequalities not only within gender (to assist crisis-hit male groups) but also between genders (to close gender gaps), is important to shed light on potential trade-offs involved. ${ }^{3}$ We find that these trade-offs depend crucially on the type of public expenditure considered.

Using micro-level data for the U.S. from the Current Population Survey (CPS), our study provides policy-making insights on the importance of the composition of government expenditure for understanding the impact of fiscal shocks on labor market outcomes across gender. We also examine the impact on demographic subgroups to assess whether fiscal expansions that close gaps can simultaneously offset inequitable business cycle impacts that particularly affect some categories of male workers. Our main findings can be summarized as follows. First, the composition of fiscal shocks matters. Spending on the government wage bill narrows gender gaps in wages and employment rates, while government purchases from the private sector and investment expenditure tend to stimulate men's wages relatively more than women's. These results are likely driven by spending components that target specific occupations and sectors which differ in their gender composition. Second, promoting gender equality through fiscal expansions is not fully compatible with offsetting other types of inequalities. The spending component that best closes gender gaps has adverse effects on labor market outcomes of cyclically vulnerable male subgroups: young, less-educated and blue-collar workers. Similarly, investment spending, which fosters employment of these crisis-hit men, is not able to reduce gender inequalities but rather contributes to widening them.

Government spending can impact labor market outcomes unequally across gender for four main reasons. First, because men and women sort into different occupations, their labor demand will shift to different extents following fiscal shocks. Such shifts will depend on which type of government spending is boosted. This motivates us to distinguish between different fiscal components in our analysis. Second, since women are more mobile across industries and occupations, ${ }^{4}$ they may be the main beneficiaries of higher wages and expanded employment opportunities after a fiscal expansion. Third, there is solid empirical evidence that female labor supply is relatively more

\footnotetext{
1 Men incurred around three-quarters of the net job losses during the Great Recession, with similar magnitudes during previous downturns (Wall and Engemann 2009). This can be ascribed partly to men's employment in more cyclical industries such as manufacturing and construction. See for instance Clark and Summers (1981), Solon et al. (1994) and Hoynes et al. (2012).

2 Figure 13 shows unemployment rates for men, women and vulnerable male subgroups for the period 1979-2019. For a more detailed analysis see Bredemeier et al. (2017b).

3 Note that fiscal policy may have long-term effects on labor market outcomes (see, e.g., Fatás and Summers 2018; Saez et al. 2019) and therefore on gender gaps. Notably, Saez et al. (2019) find evidence of stronger hysteresis effects of employment subsidies on women than men. Fiscal policy may also have a lasting impact on female labor force participation with family-friendly policies (see, e.g., Blau and Kahn 2013).

4 See, e.g., Shin (1999).
} 
elastic than male labor supply. ${ }^{5}$ Consequently, female employment may respond more strongly than male employment to fiscal shocks. Fourth, women taking up jobs may hire (usually female) caregivers for children and elderly dependents, inducing secondround employment and wage effects.

These insights can be valuable for macroeconomists and policy makers. First, our results help to gauge to what extent government expenditure is able to "assist those most impacted by the recession," which was the explicit purpose of the American Recovery and Reinvestment Act of 2009. ${ }^{6}$ Second, our analysis is insightful for policy makers whose goal is to promote female employment and gender equality, independently of the cycle. ${ }^{7}$ Conversely, this paper highlights the potential damaging effect that cutting government expenditure, especially the wage bill, may have by widening existing gender gaps. Hence, we underline the gender non-neutrality of budgetary decisions and substantiate the importance of implementing "gender budgeting" as suggested by the International Monetary Fund (2017) and the European Parliament (2015). Third, our analysis hints at the importance of encouraging women's labor force participation as this may increase the effectiveness of fiscal policy as an aggregate stabilization tool.

To measure the effects of fiscal policy shocks on gender gaps in the labor market, we estimate several vector autoregressive models using Bayesian estimation techniques. Following Mountford and Uhlig (2009), we identify the fiscal shocks using an agnostic sign restriction approach. The main advantage of this identification strategy is that it allows us to eliminate the confounding influence of other macroeconomic shocks: namely, business cycle, monetary policy and tax revenue shocks. We examine the impulse response functions (IRFs) of gender gaps in wages and employment rates to different types of government spending shocks. Our study encompasses the analysis of two dimensions of heterogeneity. First, we investigate whether the effects of fiscal policy shocks on gender gaps differ depending on the type of public expenditure. Second, we explore how the effects vary across male and female workers with different characteristics, such as age, education and occupation.

This paper relates to a strand of the literature that reports heterogeneous effects of fiscal policy across households with different characteristics (such as Giavazzi and McMahon 2012; Misra and Surico 2014 and Anderson et al. 2016), and across industries (notably, Nekarda and Ramey 2011 and Bredemeier et al. 2020). Several studies have emphasized the crucial role of industry composition in shaping gender differences in labor market outcomes, including Hoynes et al. (2012), Olivetti and Petrongolo (2014) and Bredemeier et al. (2017b). However, despite a growing interest in the evolution and the determinants of gender gaps in the labor market, ${ }^{8}$ the literature

\footnotetext{
5 See, e.g., Cogan (1981), Eckstein and Wolpin (1989), van der Klaauw (1996) and Francesconi (2002).

6 This stimulus package, worth $\$ 787$ billion, consisted of a mix of tax credits, spending on social welfare, consumption spending (mainly on education and healthcare) and investments in infrastructure and the energy sector.

7 Our results suggest that the impact of fiscal policy on gender gaps can be quite persistent. In addition, government expenditure shocks show a high degree of persistence. We find estimates of the autocorrelation coefficients of the cyclical component for government spending instruments that are larger than 0.9 and highly statistically significant.

${ }^{8}$ See, e.g., Blau and Kahn (2000), Blau and Kahn (2017), Ngai and Petrongolo (2017) and Albanesi and Şahin (2018).
} 
on the impact of fiscal policy on gender equality is scarce. A few recent studies document that fiscal expansions stimulate primarily female employment, in particular Bredemeier et al. (2017b) and Akitoby et al. (2019). These papers focus on the effects of total government spending. Our main contribution to the existing literature is to explore the effects of various components of public expenditure. We argue that who benefits from fiscal stimuli depends on the type of expenditure under consideration. We also analyze labor market outcomes for male subgroups that are hurt most during recessions to better understand the trade-offs involved when attempting to close gender gaps. Furthermore, our identification strategy is able to better isolate the variations in fiscal policy variables from automatic responses to other macroeconomic shocks.

The remainder of this paper is structured as follows. Sections 2 and 3 describe the data and the econometric approach. Results are presented in Sect. 4 and robustness checks and extensions are described in Sect. 5. Section 6 concludes by offering directions for future research. The appendices contain some stylized facts about the components of government expenditure and gender compositions across occupations and sectors. Furthermore, we provide a description of the data and of the algorithm used for estimating the impulse response functions.

\section{Data}

We construct labor market series using micro-level data from the Centre for Economic Policy Research (CEPR) extracts of the CPS Merged Outgoing Rotation Groups. ${ }^{9} \mathrm{We}$ build quarterly series for real hourly wages and employment rates for each gender and for subgroups most exposed to cyclical fluctuations, i.e., those (i) without college education, (ii) aged 16 to 30 and (iii) in blue-collar occupations (mainly production, construction, transport, and installation). ${ }^{10}$ Following the approach described in the seminal paper by Deaton (1985), we build pseudo-panels by aggregating individual observations into pseudo-cohorts of workers with similar characteristics and computing averages for each period. ${ }^{11}$ We restrict the sample to full-time workers aged 16-64, i.e., who have worked at least 35 hours a week. ${ }^{12}$ Self-employed workers are excluded. ${ }^{13}$ All variables are seasonally adjusted by X-12 ARIMA. Data on fiscal vari-

\footnotetext{
9 The CPS is the source of official US government statistics on employment, wages and unemployment, with interviewed households selected to be representative of the US population.

10 To build occupational employment groups, we use the conversion factors from the U.S. Census Bureau as the occupation and industry codes in the CPS were subject to several revisions. As defined in Bredemeier et al. (2020), blue-collar occupations include construction and extraction occupations; installation, maintenance, and repair occupations; production occupations; and transportation and material moving occupations. Note that these occupations have a female share of less than $50 \%$ for the whole sample period.

11 We compute quarterly averages of monthly observations.

12 In Sect. 5, we also conduct the analysis for non-married individuals, to exclude partner effects, and for part-time workers.

13 We have excluded the self-employed since their wages, employment status and hours worked are difficult to measure accurately. As Hamilton (2000) points out, earnings of business owners are less reliable because of tax incentives to under-report income. Moreover, other forms of "indirect" compensation, such as pensions and health insurance contributions that are paid for employees by the employer, are not received by the self-employed, making it hard to compare incomes.
} 
ables, GDP and inflation are from the U.S. Bureau of Economic Analysis, on civilian population from the U.S. Bureau of Labor Statistics, and on the federal funds rate from FRED. Details of sources and definitions of the data are provided in Appendix E.

Figure 12 shows the historical evolution of each fiscal component between 1979 and 2019. Total government spending consists of government consumption expenditures and gross investment. ${ }^{14}$ In turn, consumption expenditures include compensation of general government employees (the wage bill), consumption of fixed capital, and purchases of intermediate goods and services from the private sector. While real government spending per capita has nearly quintupled since the start of our sample, the relative shares of its components have remained fairly stable, except for purchases from the private sector, which have grown from $21 \%$ in 1979 to $28 \%$ in 2019 . The wage bill is the largest component, with a share of $45 \%$ of total government expenditure on average over 1979-2019, while investment spending accounts for about $19 \%$ of total government spending.

Gender gaps have narrowed over the sample period, especially during the 1980s, driven by the rise in female labor force participation; but they remain significant. In 1979, full-time female workers earned around $40 \%$ less per hour than male workers and their employment rate was $27 \%$ lower than men's. In 2019, gaps in wages and employment were about $18 \%$ and $15 \%$ respectively (see also Appendix A).

\section{Econometric approach}

\subsection{VAR model}

To measure the effects of different types of government expenditure on gender gaps in the labor market, we estimate several structural vector autoregressive (VAR) models with up to nine endogenous variables.

In our baseline specification, the vector of endogenous variables first includes the three fiscal components of interest: namely, the log of real per capita government expenditure on goods and services from the private sector, the log of real per capita government investment expenditure and the log of real per capita expenditure on the government wage bill. ${ }^{15}$ Next, the variables included are the log of real per capita net (of transfers) tax revenue, the log of real per capita GDP, the labor market gap variable, inflation and the federal funds rate.

The labor market gap variable alternates between the gender gap in (i) hourly wages and (ii) employment rates. The gender wage gap is measured as the difference between the log of real male wages and the log of real female wages. The gender gap in employment rates is defined as the difference between male and female rates.

\footnotetext{
${ }^{14}$ Consumption expenditures consist of spending by the government to produce and provide services to the public, such as national defense and public school education. Gross investment consists of expenditure by the government in structures that directly benefit the public, such as highways, as well as in equipment, software and R\&D that assist government agencies in their production activities, such as purchases of military hardware.

15 Results for government expenditure on purchases of goods and services are similar to those obtained using non-wage government consumption, i.e., the sum of expenditure on purchases of goods and services and expenditure on fixed capital.
} 
To control for fiscal foresight, we include eight lags of an exogenous war dummy following Ramey (2011). The VAR models are estimated with two lags, on quarterly data from 1979Q1 to 2019Q4. ${ }^{16}$ Following Mountford and Uhlig (2009), we include neither a constant nor a time trend. ${ }^{17}$

In addition, we repeat the above analysis including male and female series of log real wages (respectively, employment rates) instead of gender gaps. Estimating the effects of fiscal shocks on male and female labor market outcomes separately allows us to better understand the mechanism behind changes in gender gaps and to draw finer policy conclusions.

\subsection{Identification}

Following Mountford and Uhlig (2009), Pappa (2009), Arias et al. (2018) and Bermperoglou et al. (2017) among others, we identify the fiscal shocks using an agnostic sign restriction approach that sets a minimum number of restrictions on impulse responses, while controlling for other macroeconomic shocks. These identifying sign restrictions are summarized in Table 1.

The shocks are identified sequentially, as in Mountford and Uhlig (2009), Arias et al. (2018) and Bermperoglou et al. (2017). First, we identify a generic business cycle shock that leads to a positive comovement between output and government net tax revenue for four quarters. Second, we follow Bermperoglou et al. (2017) and identify a monetary policy shock by combining zero and sign restrictions. In particular, the federal funds rate should react positively and contemporaneously to output and inflation deviations only, to approximate the Taylor rule. ${ }^{18}$ We also impose orthogonality between the monetary policy shock and the business cycle shock. Third, the government revenue shock is identified as a shock that raises net tax revenues for four quarters and that is orthogonal to the monetary and business cycle shocks. Lastly, we identify shocks to government goods purchases, a government investment shock and a government wage bill shock sequentially. We impose that these shocks increase the corresponding fiscal variable for four quarters while being orthogonal to the business cycle, monetary policy and other fiscal shocks. Orthogonality to the other fiscal shocks ensures that our results are driven exclusively by the fiscal instrument of interest and not by any other expenditure component.

Following Uhlig (2005), we estimate the model using a Bayesian approach with flat priors for model coefficients and the covariance matrix of shocks (see Appendix D). The estimations are based on 400 draws from the posterior distribution of VAR parameters and 4000 draws of orthonormal matrices. We compute the median, the $68 \%$ and the $90 \%$ confidence bands of impulse responses to a shock that raises the government expenditure component of interest by $1 \%$ on impact.

\footnotetext{
16 The starting date of the sample is constrained by the availability of CPS MORG data. Results are qualitatively similar when the sample ends in 2007Q4.

17 We checked that the results are qualitatively robust when a constant and a time trend are included.

18 Since we use quarterly data, we believe that the assumption that the policy rate only responds within the first quarter and shows no sign of inertia is reasonable. In particular, Rudebusch (2006) finds little evidence of a sluggish adjustment of interest rates for the Fed at the quarterly frequency.
} 
Table 1 Identifying sign restrictions

\begin{tabular}{lllllll}
\hline Restricted variables & Shocks & & & & & \\
\cline { 2 - 6 } & $\varepsilon_{t}^{G P}$ & $\varepsilon_{t}^{G_{I}}$ & $\varepsilon_{t}^{G_{W}}$ & $\varepsilon_{t}^{T}$ & $\varepsilon_{t}^{M P}$ & $\varepsilon_{t}^{B C}$ \\
\hline Output & & & & & & + \\
Inflation rate & & & & & \\
Interest rate & & & + & & + \\
Government revenue & + & & & & \\
Government purchases & + & & & \\
Government investment & & + & + & & \\
Government wage bill & & & + & & \\
\hline
\end{tabular}

This table reports the sign restrictions on impulse responses for each identified shock. $\varepsilon_{t}^{G_{P}}$ denotes a shock to government purchases of goods and services, $\varepsilon_{t}^{G_{I}}$ denotes a government investment shock, $\varepsilon_{t}{ }_{W}$ a government wage bill shock, $\varepsilon_{t}^{T}$ a government revenue shock, $\varepsilon_{t}^{M P}$ a monetary policy shock, and $\varepsilon_{t}^{B C}$ a business cycle shock. To identify the monetary policy shock, we do not impose restrictions on the impulse response functions but on the structural impact matrix. All restrictions apply for periods 0-3 after the shock occurred

\section{Results}

This section reports our results for different government spending components. Section 4.1 looks at gender gaps among all full-time employees aged 16-64, and Sect. 4.2 analyzes heterogeneities across subgroups, obtained by further splitting the sample by age, education and occupation. The purpose of this exercise is threefold. First, it helps us to gain insights into whether spending components have asymmetric effects across men and women. Second, it allows for a better assessment of how to use fiscal policy to offset inequitable business cycle effects across other socioeconomic dimensions. Third, the analysis highlights trade-offs involved when attempting to close gender gaps since demographic subgroups may not react equally to fiscal stimuli. Overall, we find that gender gaps close most strongly following a shock to the government wage bill. ${ }^{19}$ However, this spending component amplifies the particularly adverse effects experienced by certain male subgroups during recessions.

\subsection{The effect on gender gaps differs across fiscal components}

Figure 1 shows the responses of gender gaps in wages (first row) and employment rates (second row) to shocks that raise the government wage bill, government purchases from the private sector and government investment by $1 \%$ on impact, respectively. The effects of an increase in government purchases and investment expenditure on gender gaps are small in magnitude and mostly not statistically significant. In contrast, a positive government wage bill shock significantly reduces both wage and employment gaps between genders.

\footnotetext{
19 We also find clear-cut evidence of a Granger-causality from government expenditure to gender gaps, but little evidence of causality in the opposite direction. Results are available upon request.
} 

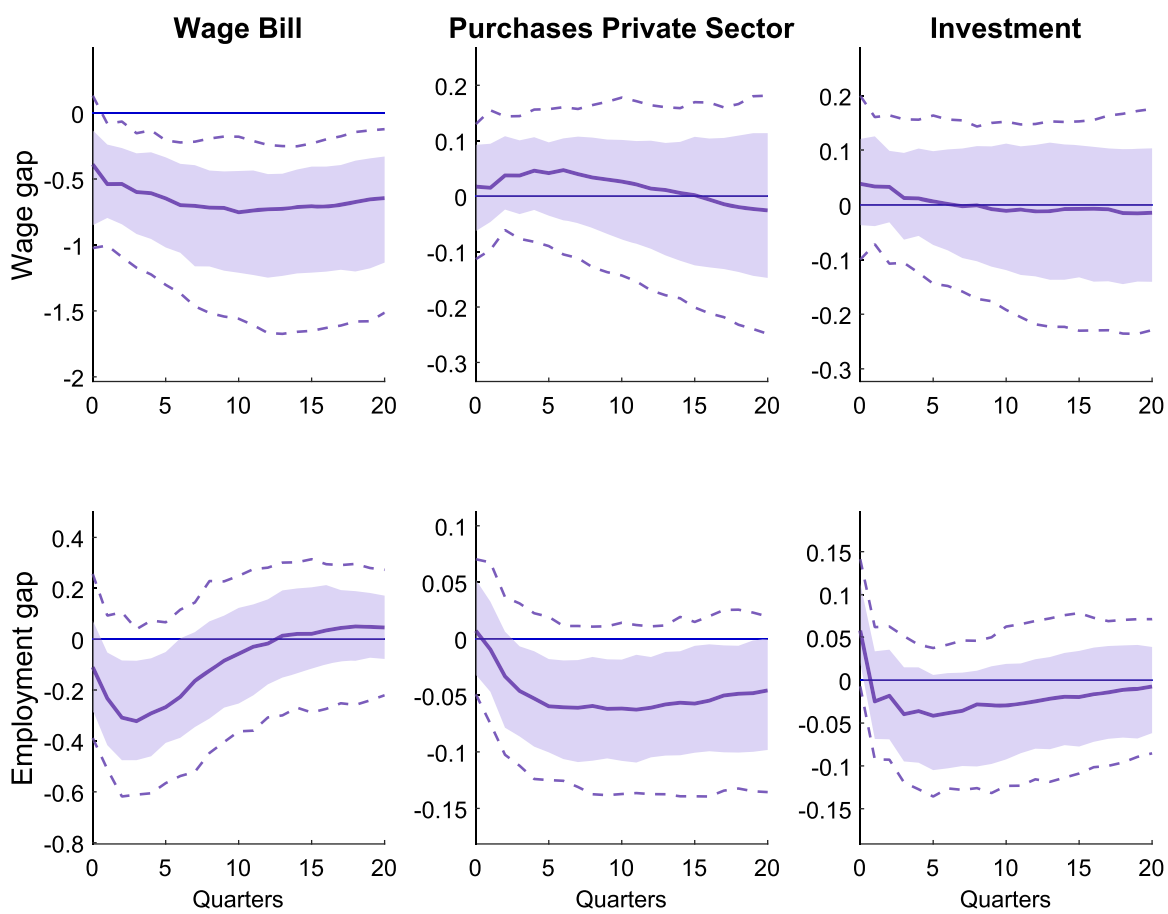

Fig. 1 IRFs of gender gaps to shocks in different spending components. Notes Dashed lines and shaded areas indicate the $90 \%$ and the $68 \%$ confidence bands respectively

Exploring the effects of a wage bill shock on full-time men and women separately reveals that the reduction in wage gaps is driven by a significant increase in female wages and a fall in male wages (Fig. 4). In addition, the employment gap closes since employment falls among men but remains unchanged among women. Expansions in government purchases and investment spending lead to a rise in male wages in the short run, leaving female wages unchanged, and a reduction in employment rates for both genders in the medium run.

To start with, note that, overall, these government spending shocks tend to have positive effects on wages (for women in the case of a wage bill shock, for men in the case of goods purchases and investment spending shocks) but negative effects on employment. As Finn (1998) showed, an increase in the number of public employees is predicted to crowd out private employment. Increases in public wages or employment also put upward pressure on private sector wages, inducing a negative labor demand effect. In addition, if the fiscal expansion is financed with increased labor income taxes, workers may reduce their labor supply or ask for higher pre-tax real wages. These results are also in line with empirical findings reported in Alesina et al. (2002) and Ramey (2013). Alesina et al. (2002) show that increases in public spending raise labor costs and lead to declining profits. Ramey (2013) provides evidence that increases in government purchases of private goods and in the government wage bill have negative effects on private activity and employment. 
Next, we observe differences in labor market outcomes across gender depending on the type of fiscal shock considered. Women benefit most from an increase in the wage bill, while men are the main beneficiaries of expansions in government purchases and investment expenditure. These findings are likely driven by spending components that target specific sectors and occupations which differ in their gender composition. Hence, men and women face different shifts in labor demand.

Government purchases from the private sector and investment expenditure mainly target manufacturing, construction and transportation industries, which are male dominated. In contrast, increases in public sector employment or wages should benefit women disproportionately as they are over-represented in this sector, with an average share of $53 \%$ during our sample, as compared with $42 \%$ in the private sector. Thus, the reduction in the gender wage gap after a shock to public sector wages is partly a mechanical outcome. In addition, increasing the public sector head count will attract women disproportionately since they are offered a relatively higher public sector wage premium compared with men (see Figs. 14 and 15). ${ }^{20}$ Moreover, women in the private sector may find it easier to transition to the public sector since, unlike men, they mirror the occupational structure of their public sector counterparts. In both sectors, a disproportionate share of women work in healthcare, education and administrative jobs (see Figs. 16 and 17). ${ }^{21}$ Thus, following a wage bill shock, the negative employment effects described above for the whole population are offset for women but not for men. In addition, women taking up government jobs may hire (usually female) caregivers for children and elderly dependents, which may induce second-round employment and wage effects. ${ }^{22}$

Furthermore, as documented in Bredemeier et al. (2020), expansions in government consumption - most of which are dedicated to the government wage bill-lead to a shift from blue-collar to pink-collar employment. ${ }^{23}$ The authors show that this heterogeneity in occupational employment dynamics can be explained by differences in substitutability between labor and capital services across occupations. ${ }^{24}$ The shift from blue- to pink-collar jobs in the private sector may also occur as a result of public-sector outsourcing. A shock to the wage bill may therefore increase demand for female-dominated jobs in the private sector, such as in healthcare, education and

\footnotetext{
20 In 2015, full-time median earnings of women amounted to only $75.8 \%$ of male earnings in the private sector but $84 \%$ in state and local government jobs and $88.5 \%$ at the federal government level (American Community Survey, see Fig. 15). Besides the higher wage premium, women's stronger appeal of the public sector may also be driven by higher levels of job protection and family-friendly work arrangements (see Kolberg 1991; Gomes and Kuehn 2019).

21 In contrast, men do not perform the same jobs across the two sectors. Public sector male employees mainly cluster in protective services and education, while men in the private sector are over-represented in construction, installation, production and transportation occupations.

22 For instance, Connelly and Kimmel (2003) find that, independently of marital status, female labor supply has a positive effect on demand for formal childcare.

23 See also Bredemeier et al. (2017a).

24 As discussed in Bredemeier et al. (2020), capital services and blue-collar labor, which includes mainly manual tasks, tend to be close substitutes. In contrast, pink-collar labor, which usually requires more social skills, is a poor substitute for capital services. As labor supply is less elastic than capital services, demand for pink-collar workers rises disproportionately after a fiscal expansion.
} 
administration. ${ }^{25}$ In contrast, these changes in labor demand contribute to amplifying the adverse effects on wages and employment for male workers, in particular after a wage bill shock.

To summarize, we find that men and women are affected differently by the three types of public expenditure. Our results suggest that increases in the government wage bill, which is the largest component of government expenditure, affect women more favorably than men. Gender-specific sectoral and occupational sorting may explain heterogeneous responses to different fiscal shocks. In the next section, we split workers further into demographic subgroups to explore how crisis-hit men respond to increases in these different types of government expenditure.

\subsection{Female-friendly spending harms cyclically vulnerable men}

It is well documented that business cycle fluctuations affect male workers disproportionately, especially those who are younger, less educated or work in blue-collar occupations. ${ }^{26}$ Our analysis reveals that the same groups of men are hurt by shocks to the government wage bill-the instrument that best closes gender gaps.

Figures 2 and 3 show the impulse response functions of wages and employment rates, respectively, to shocks in each spending component for the male subgroups hit hardest during recessions, i.e., the young, the less educated and blue-collar workers. Spending on the government wage bill (first column of Fig. 2) strongly reduces men's wages in all subgroups in the medium run and has no statistically significant impact on their employment (first column of Fig. 3). In contrast, shocks to both government purchases and investment spending lead to an increase in wages among these subgroups in the short run. Furthermore, investment spending raises employment significantly among all these categories of male workers, and government goods purchases stimulate employment of blue-collar men.

As discussed previously, men are particularly negatively affected by increases in the government wage bill, since they cannot easily move to the public sector and since demand for their labor in the private sector is adversely affected by the shift from blueto pink-collar employment. This may explain why male wages decrease substantially among these subgroups after a wage bill expansion, while female wages remain unaffected or increase, resulting in narrower gender gaps (see Fig. 5). In contrast, shocks to investment and goods purchases strongly stimulate demand in manufacturing, construction, installation and transportation sectors. In particular, manufacturing firms receive the largest share of government contracts. ${ }^{27}$ The fact that young, less-educated and blue-collar male workers are over-represented in these sectors may explain why they strongly benefit from these fiscal shocks. Conversely, women belonging to these

\footnotetext{
25 In fact, when we estimate wage and employment responses in the private sector and public sector separately, we find that the negative effects on male employment and wages for the total population are driven largely by men's losses in the private sector (see Fig. 8).

26 See, e.g., Wall and Engemann (2009) and Fig. 13.

27 Between 2001 and 2018, manufacturing firms received $31 \%$ of public spending on private-sector goods and services (Cox et al. 2020).
} 

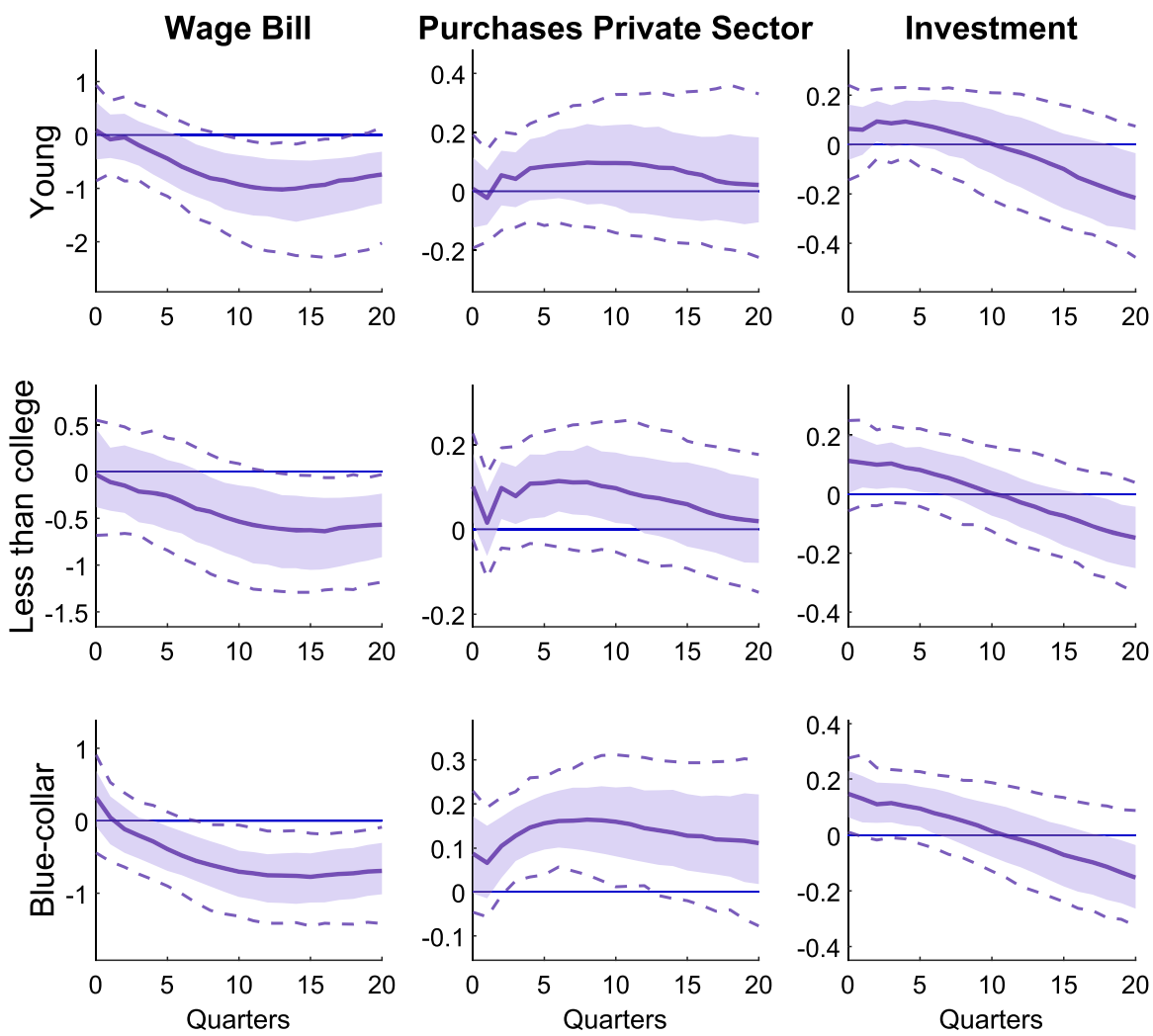

Fig. 2 IRFs of wages for male subgroups to shocks in different spending components. Notes Dashed lines and shaded areas indicate the $90 \%$ and the $68 \%$ confidence bands respectively

subgroups benefit less from increases in government investment, which significantly raises gender gaps (see Fig. 7).

Overall, we find that the fiscal instrument that is most useful for closing gender gaps in the whole population - the government wage bill-decreases wages of crisisprone men. Conversely, government investment spending, which benefits cyclically vulnerable men, is less suitable for tackling gender inequalities.

\section{Robustness checks and extensions}

We consider several robustness checks and extensions of our main results. These include: (i) using an alternative identification scheme-namely, a recursive (Cholesky) identification; (ii) restricting the sample to part-time workers; and (iii) restricting the sample to unmarried workers.

Figure 9 displays the impulse responses of gender gaps for the total population that result from identifying fiscal shocks recursively using a Cholesky decomposition. The ordering of endogenous variables is the same as in the baseline VAR specification. 

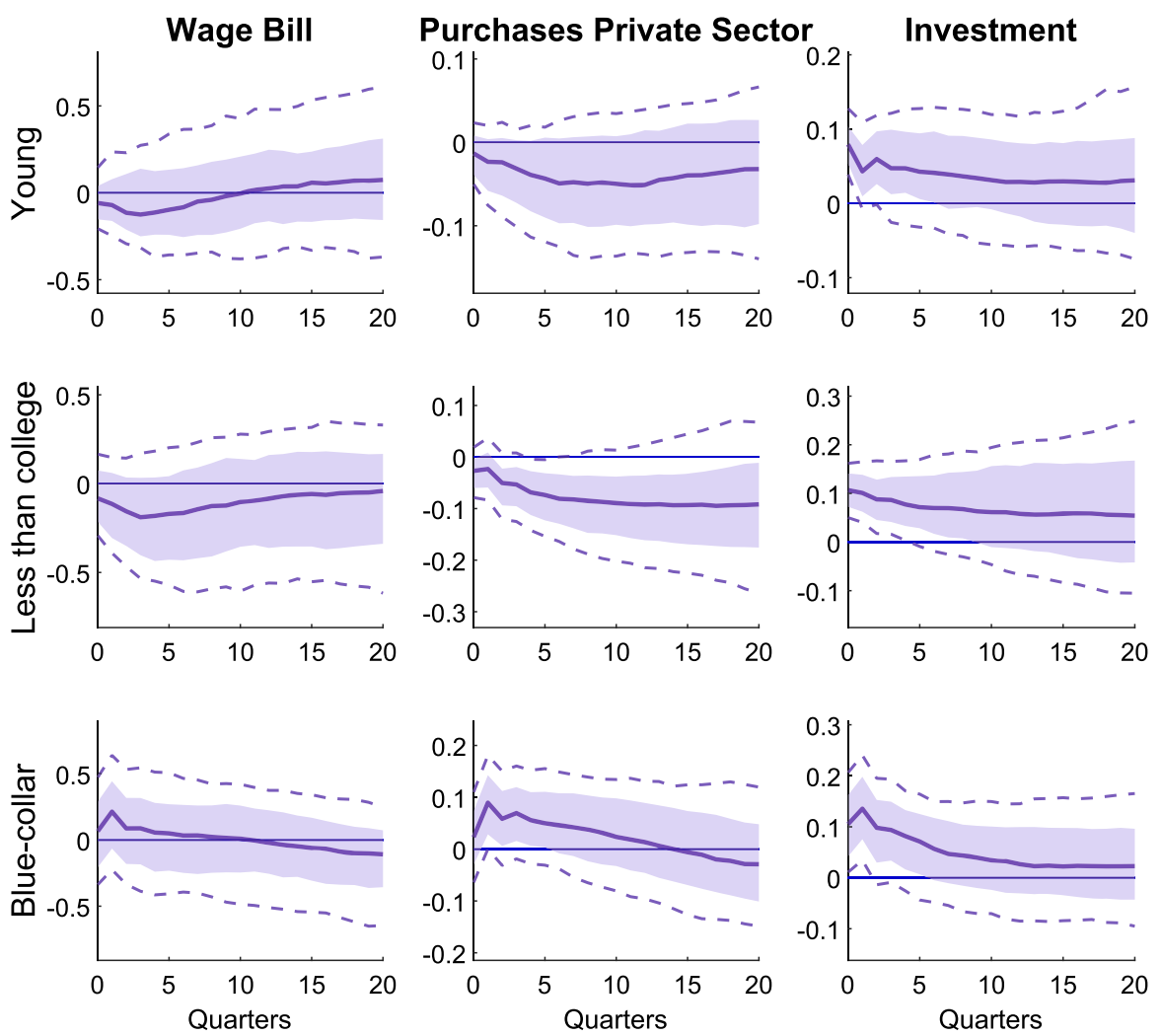

Fig. 3 IRFs of employment for male subgroups to shocks in different spending components. Notes Dashed lines and shaded areas indicate the $90 \%$ and the $68 \%$ confidence bands respectively

Overall, the results are qualitatively and quantitatively similar to our baseline except that the wage gap no longer closes after an increase in government purchases from the private sector.

Conducting our analysis for part-time workers (i.e., working less than 35 hours per week) reveals substantial differences (see Fig. 10) compared with our baseline sample consisting of only full-time workers. ${ }^{28}$ The wage and employment gaps now increase after a shock to the government wage bill. A potential explanation is that part-time private-sector women work in different occupations than their public-sector counterparts, while the occupational structure for full-time women is similar in private and public sectors. For example, female part-time workers are less likely to work in administrative jobs (see Fig. 18); thus, they benefit less from wage bill expansions because moving to the public sector is more difficult. The opposite holds for part-time male workers. They are more likely than full-time male employees to hold administrative jobs (see Fig. 19), allowing them to transfer to public-sector jobs as the wage bill rises. Another interesting difference is that the effects of government spending shocks on

\footnotetext{
28 When analyzing the labor market responses jointly for part- and full-time workers, we find similar results to those that consider only full-time workers. The associated plots are available upon request.
} 
employment are more positive for part-time than for full-time workers. This could be explained by part-time workers being hired to meet temporarily higher labor demand after a spending shock.

Lastly, in order to verify robustness and exclude partner effects, we re-run all estimations for full-time non-married workers. Our baseline results are largely confirmed (see Fig. 11). In particular, the insight that the government wage bill is the most powerful fiscal instrument to close gender gaps remains intact.

\section{Conclusions}

In this paper, we analyzed the labor market effects of fiscal policy shocks from a gender perspective, with special emphasis on the role of distinct spending components. We find that they affect men and women differently and that the effect also varies by demographic subgroup. Thus, policy makers may alter the composition of expenditures according to their objectives. If their goal is to decrease gender gaps in wages and employment, expanding the government wage bill is most appropriate. However, if the fiscal authority aims to assist young, less-educated and blue-collar men who are most affected by negative business cycle shocks, investment spending is the preferable fiscal tool. Hence, these two goals are not perfectly aligned.

Our analysis points at the importance of fostering cross-occupational mobility. If men were able to easily move to less cyclical jobs or to the public sector when the need arises, they could be better sheltered from adverse business cycle and fiscal policy effects. Moreover, our findings indicate potentially large costs of austerity for women's wages and employment, especially in case of cuts to the government wage bill. However, by estimating a linear VAR we are not able to assess whether the effects of austerity on gender gaps differ from those of fiscal expansions. Knowledge of which spending components to cut in times of tight budgets without widening gender gaps is still wanting. ${ }^{29}$ Future research should also explore whether fiscal policy has asymmetric effects on men and women depending on the state of the cycle. This would allow for a better assessment of how to offset inequitable effects during economic slumps. ${ }^{30}$ Furthermore, investigating the gender implications of financing fiscal expansions through tax or deficit increases is a relevant policy issue that needs to be addressed. Finally, since women respond more positively to the major spending component, that is, the government wage bill, encouraging their labor force participation may enhance the efficiency of fiscal policy as a stabilization tool—a conjecture for which further evidence is needed.

Open Access This article is licensed under a Creative Commons Attribution 4.0 International License, which permits use, sharing, adaptation, distribution and reproduction in any medium or format, as long as you give

\footnotetext{
29 Perugini et al. (2019) find evidence of widening gender wage gaps for the EU-28 countries after both tax-based and expenditure-based measures implemented between 2010 and 2013. However, the authors do not distinguish between spending components and do not consider gender employment gaps.

30 Akitoby et al. (2019) study the effect of government spending during recessions on the gender employment gap. However, the authors do not analyze state-dependent effects on the wage gap and do not distinguish by spending component or demographic subgroup.
} 
appropriate credit to the original author(s) and the source, provide a link to the Creative Commons licence, and indicate if changes were made. The images or other third party material in this article are included in the article's Creative Commons licence, unless indicated otherwise in a credit line to the material. If material is not included in the article's Creative Commons licence and your intended use is not permitted by statutory regulation or exceeds the permitted use, you will need to obtain permission directly from the copyright holder. To view a copy of this licence, visit http://creativecommons.org/licenses/by/4.0/.

\section{A Tables}

See Table 2 .

Table 2 Summary statistics of labor market variables for full-time workers and of government expenditure, 1979-2019

\begin{tabular}{lllll}
\hline Variable & Mean & SD & Min & Max \\
\hline Wages & & & & \\
Women's hourly real wage (USD) & 19.24 & 2.41 & 15.17 & 23.67 \\
Men's hourly real wage (USD) & 24.36 & 1.63 & 22.33 & 27.87 \\
Gender wage gap, $\ln \left(w^{\text {male }}\right)-\ln \left(w^{\text {fem }}\right)$ & 0.24 & 0.07 & 0.15 & 0.42 \\
Employment & & & & \\
Women's employment rate & 0.44 & 0.03 & 0.36 & 0.50 \\
Men's employment rate & 0.62 & 0.03 & 0.57 & 0.67 \\
Gender employment gap & 0.18 & 0.03 & 0.13 & 0.28 \\
Government expenditure per capita & & & & \\
Wage bill (USD) & 4477 & 1769 & 1564 & 7434 \\
Purchases of intermediate goods (USD) & 2650 & 1,242 & 697 & 4,707 \\
Investment (USD) & 1872 & 629 & 670 & 2972 \\
\hline
\end{tabular}

Source: Own calculations based on CEPR-CPS MORG and BEA

\section{B Figures}

See Figs. 4, 5, 6, 7, 8, 9, 10, and 11. 

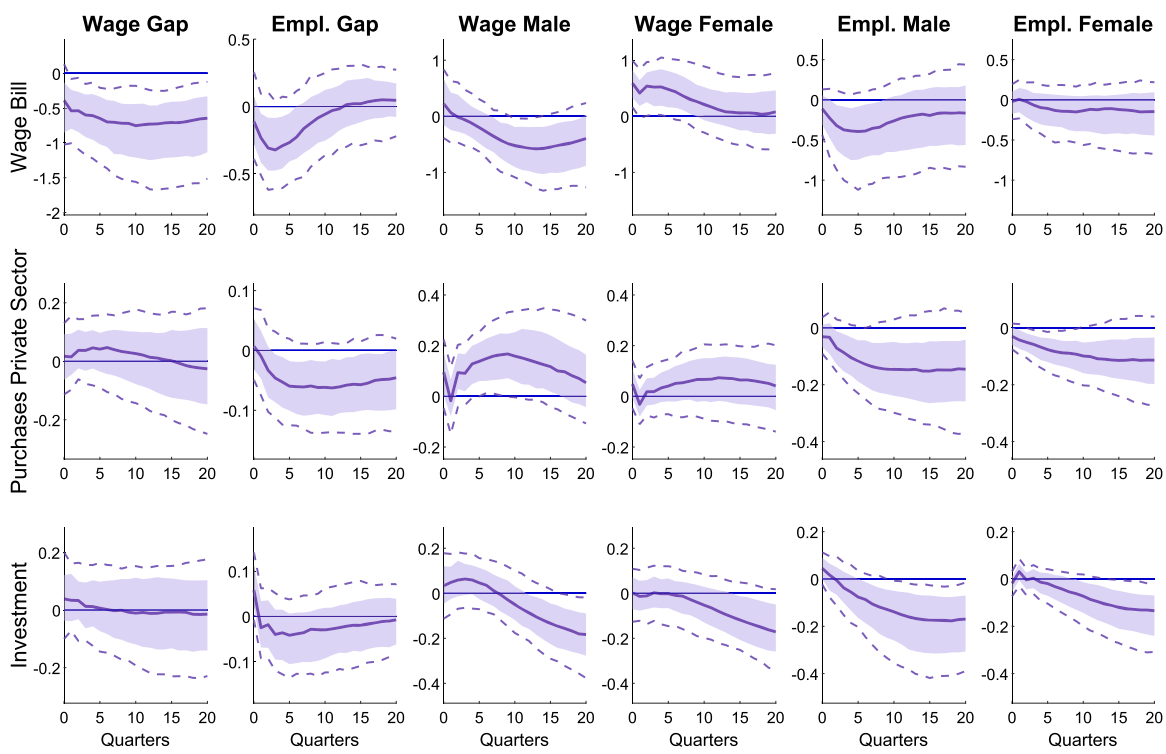

Fig. 4 IRFs of wages and employment rates to different spending shocks. These graphs plot the responses of gender gaps together with the responses of male and female variables. Notes Dashed lines and shaded areas indicate the $90 \%$ and the $68 \%$ confidence bands respectively
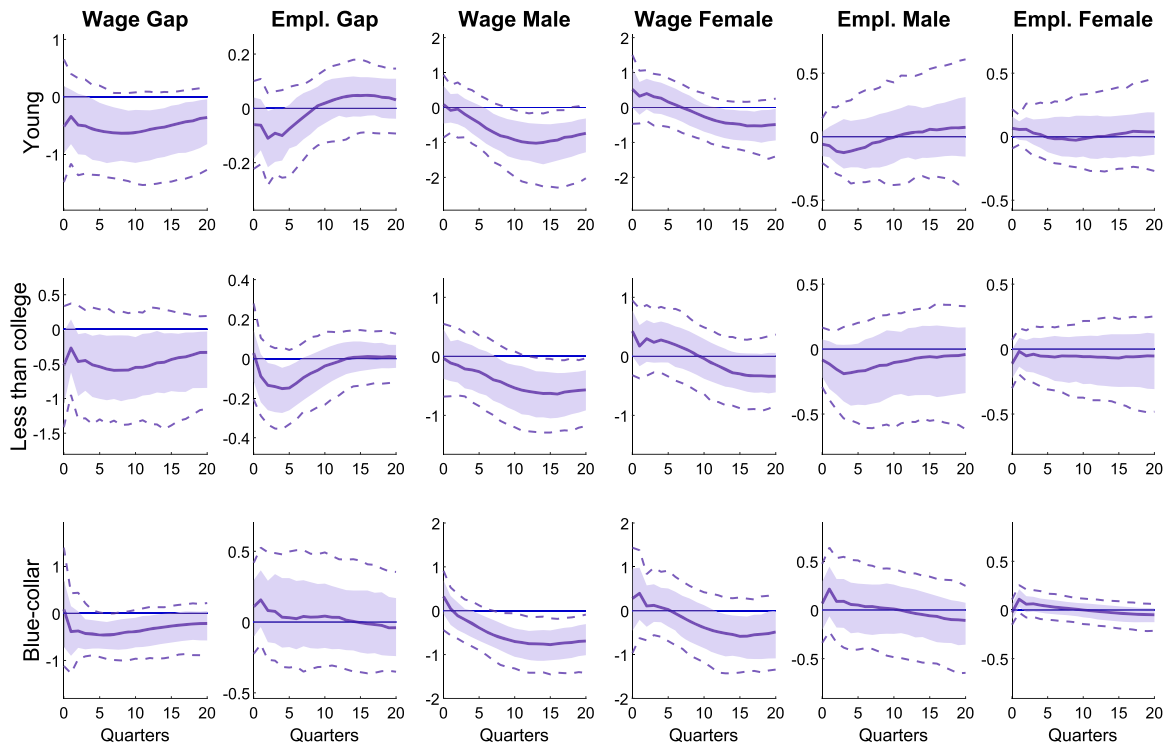

Fig. 5 IRFs of wages and employment rates for young, less-educated and blue-collar workers to shocks to the government wage bill. These graphs plot the responses of gender gaps together with the responses of male and female variables. Notes Dashed lines and shaded areas indicate the $90 \%$ and the $68 \%$ confidence bands respectively 

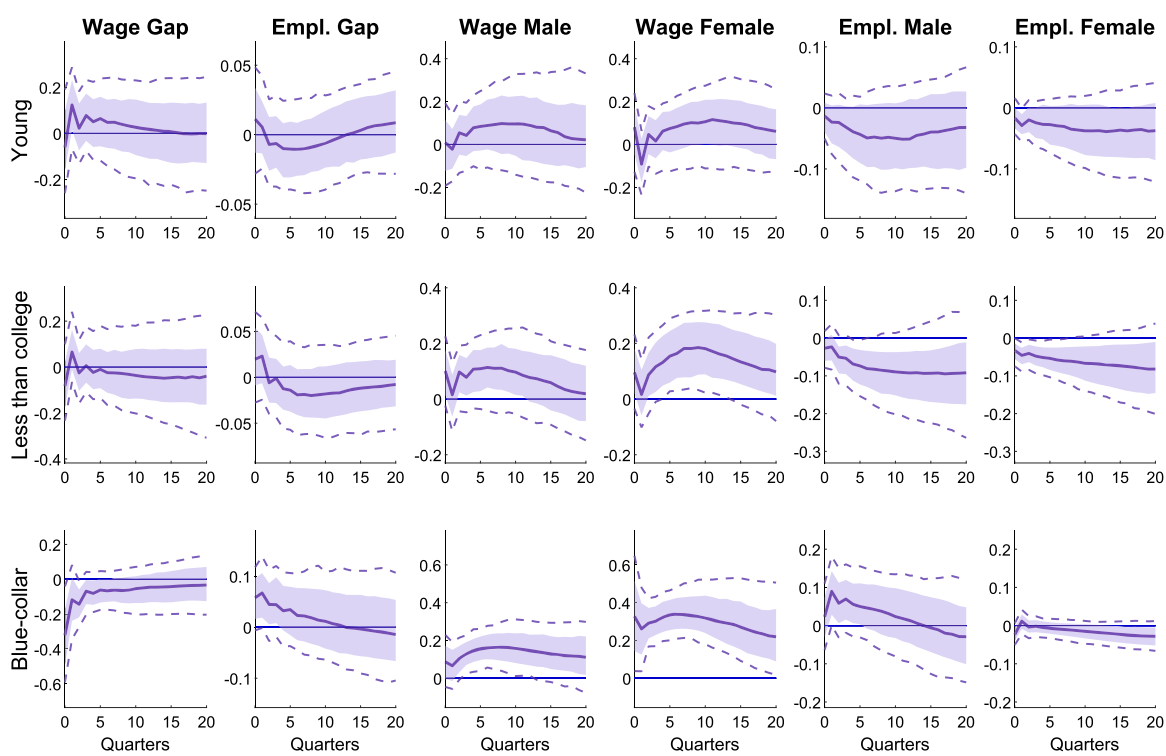

Fig. 6 IRFs of wages and employment rates for young, less-educated and blue-collar workers to shocks to government purchases of goods and services. These graphs plot the responses of gender gaps together with the responses of male and female variables. Notes Dashed lines and shaded areas indicate the $90 \%$ and the $68 \%$ confidence bands respectively
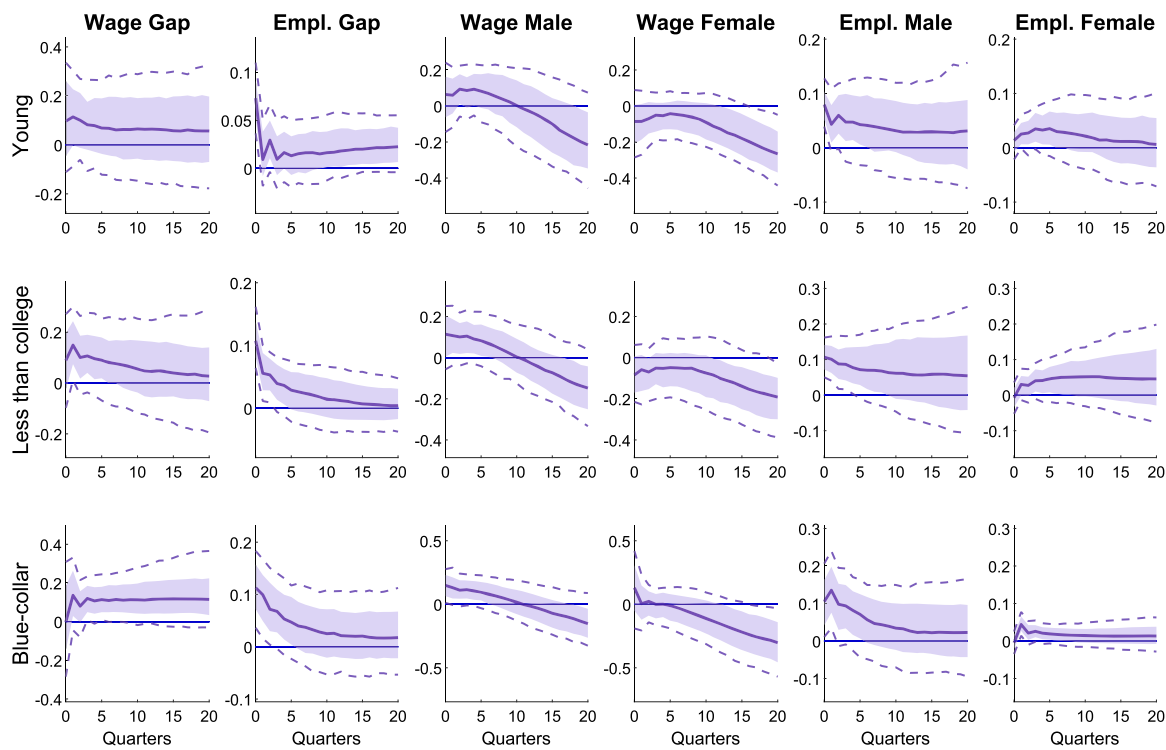

Fig. 7 IRFs for wages and employment rates for young, less-educated and blue-collar workers to shocks to government investment spending. These graphs plot the responses of gender gaps together with the responses of male and female variables. Notes Dashed lines and shaded areas indicate the $90 \%$ and the $68 \%$ confidence bands respectively 

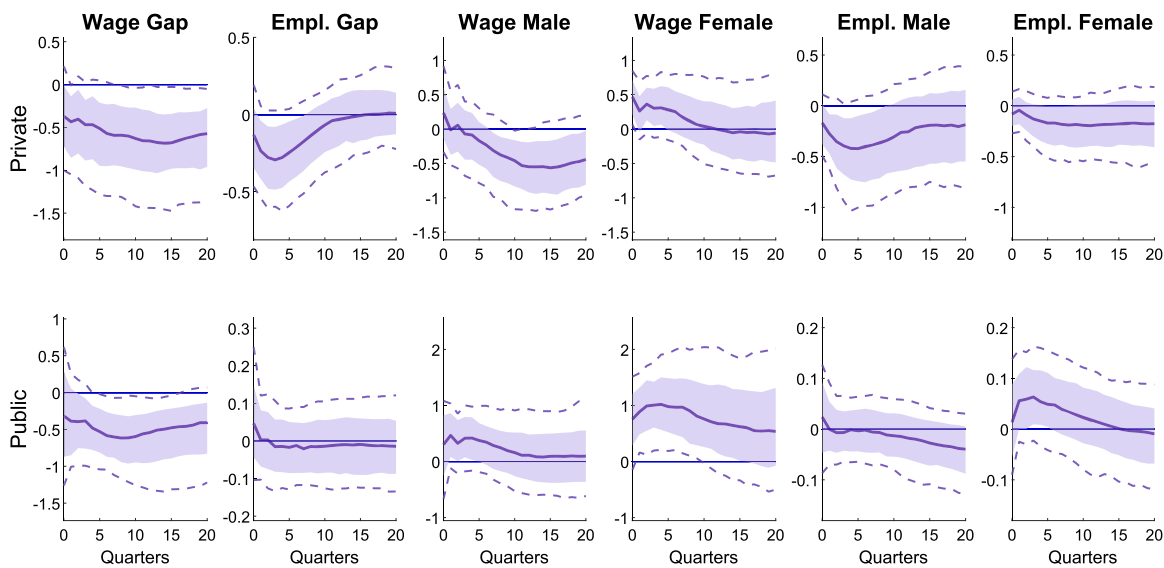

Fig. 8 IRFs of wages and employment rates for public-and private-sector workers to shocks to the government wage bill. These graphs plot the responses of gender gaps together with the responses of male and female variables. Notes Dashed lines and shaded areas indicate the $90 \%$ and the $68 \%$ confidence bands respectively
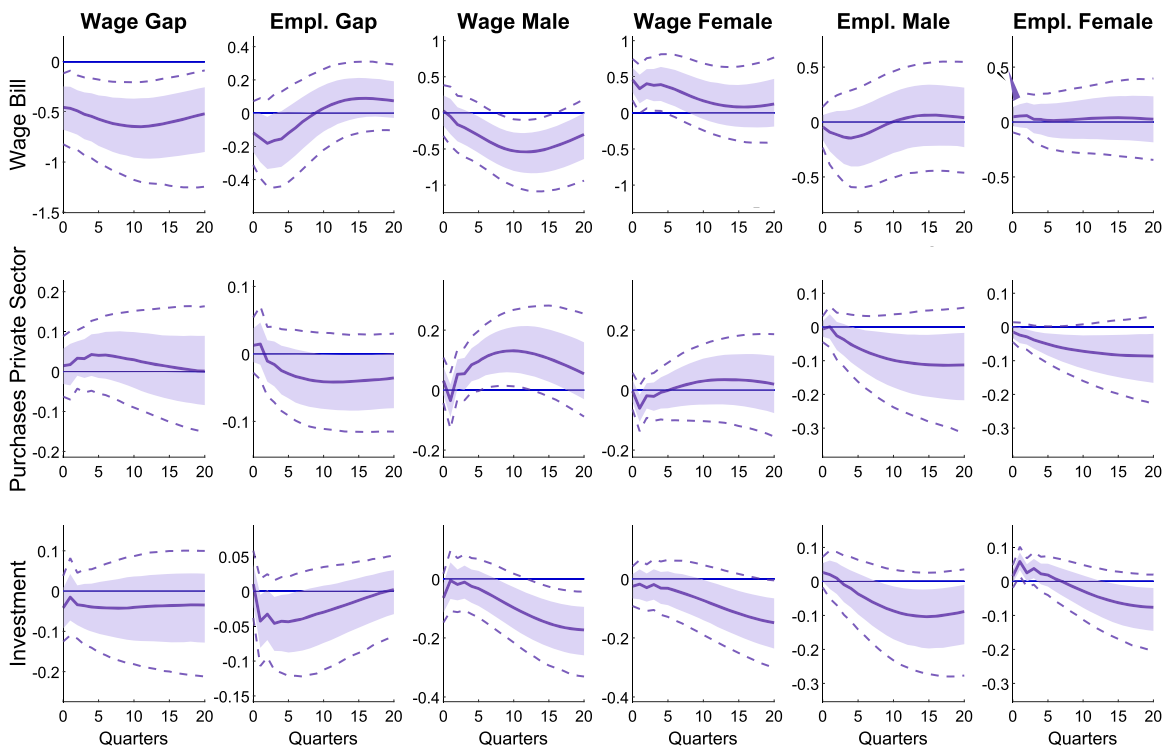

Fig. 9 IRFs of wages and employment rates to different spending shocks using a Cholesky identification. These graphs plot the responses of gender gaps together with the responses of male and female variables. Notes Dashed lines and shaded areas indicate the $90 \%$ and the $68 \%$ confidence bands respectively 

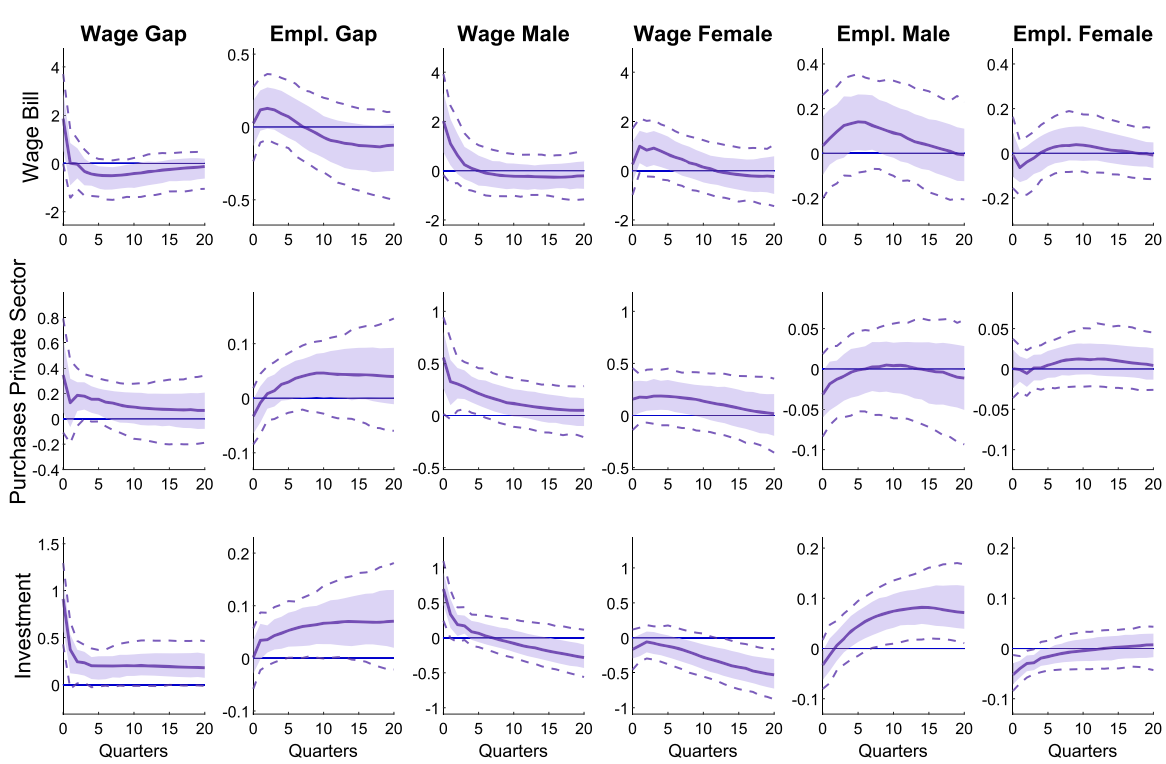

Fig. 10 IRFs of wages and employment rates for part-time workers to different spending shocks. These graphs plot the responses of gender gaps together with the responses of male and female variables. Notes Dashed lines and shaded areas indicate the $90 \%$ and the $68 \%$ confidence bands respectively
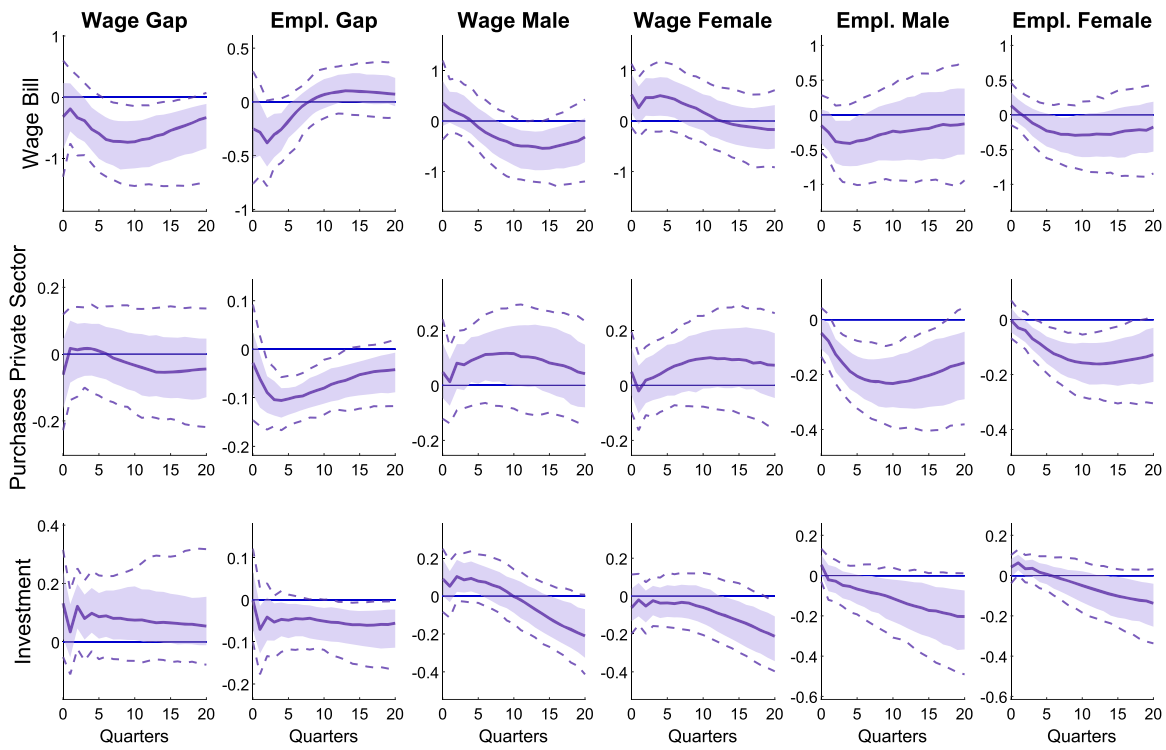

Fig. 11 IRFs of wages and employment rates for unmarried workers to different spending shocks. These graphs plot the responses of gender gaps together with the responses of male and female variables. Notes Dashed lines and shaded areas indicate the $90 \%$ and the $68 \%$ confidence bands respectively 


\section{Stylized facts}

See Figs. 12, 13, 14, 15, 16, 17, 18, and 19.

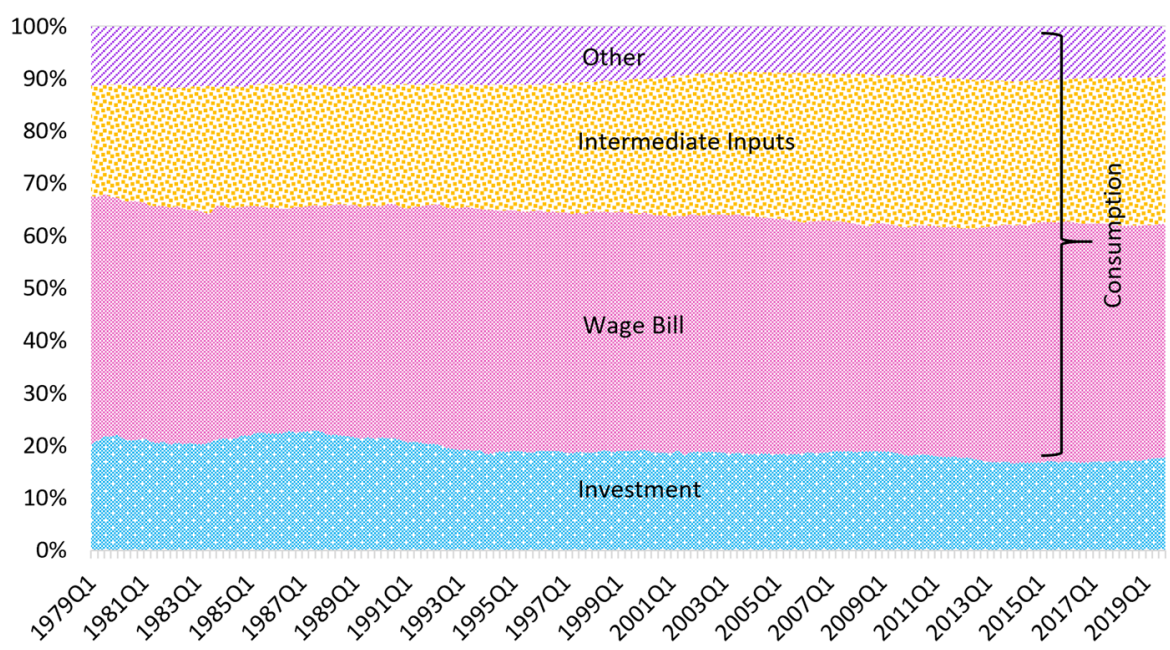

Fig. 12 Historical evolution of government spending components. Notes "Other" includes consumption of general government fixed capital. Source Bureau of Economic Analysis

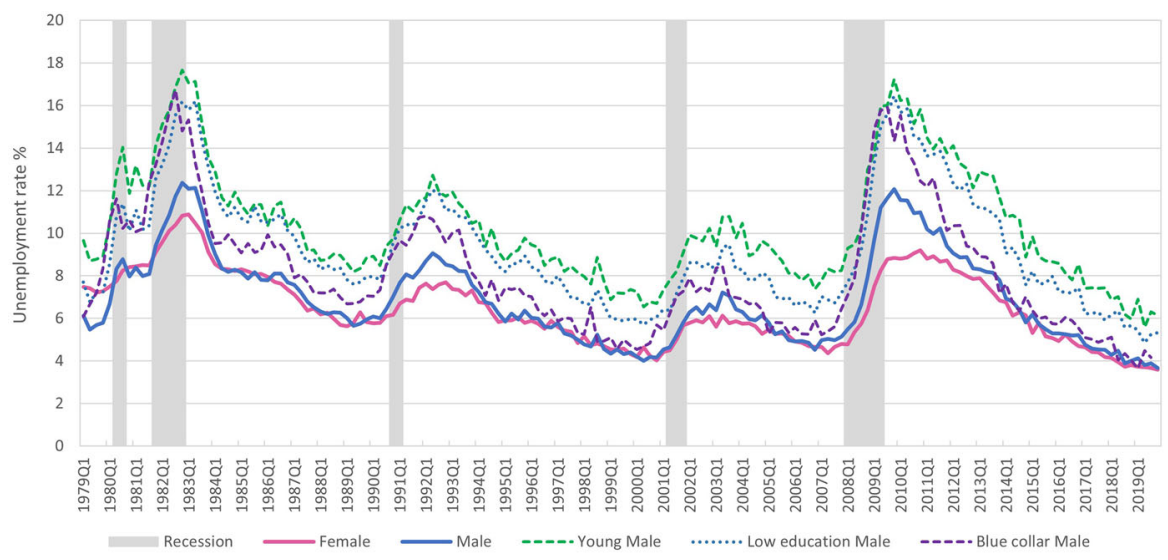

Fig. 13 Unemployment rates for population subgroups, 1979-2019. Source Own calculations based on CEPR-CPS MORG 


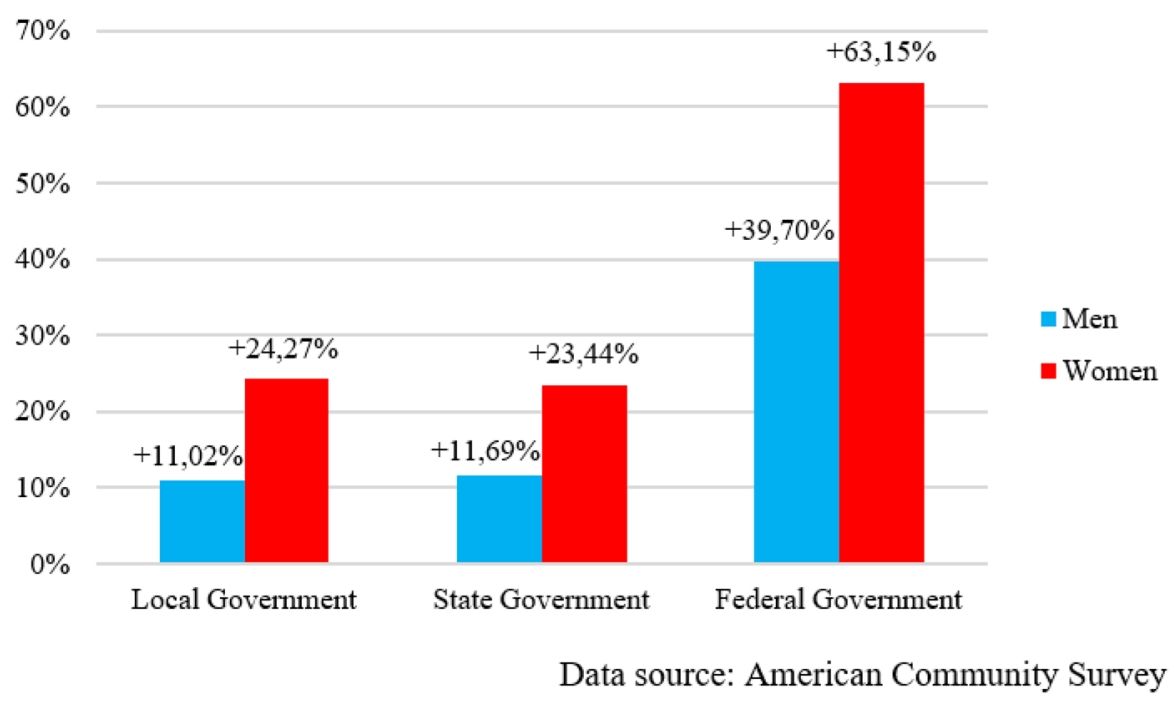

Fig. 14 Public sector wage premium compared to for-profit private sector (median full-time earnings) in 2015

$100 \%$

$95 \%$

$90 \%$

$85 \%$

$80 \%$

$75 \%$

$70 \%$

$65 \%$

$60 \%$

20052006200720082009201020112012201320142015

Private for-profit

Local Government

State Government

Federal Government

Data source: American Community Survey

Fig. 15 Female-to-male full-time median earnings ratio by sector 


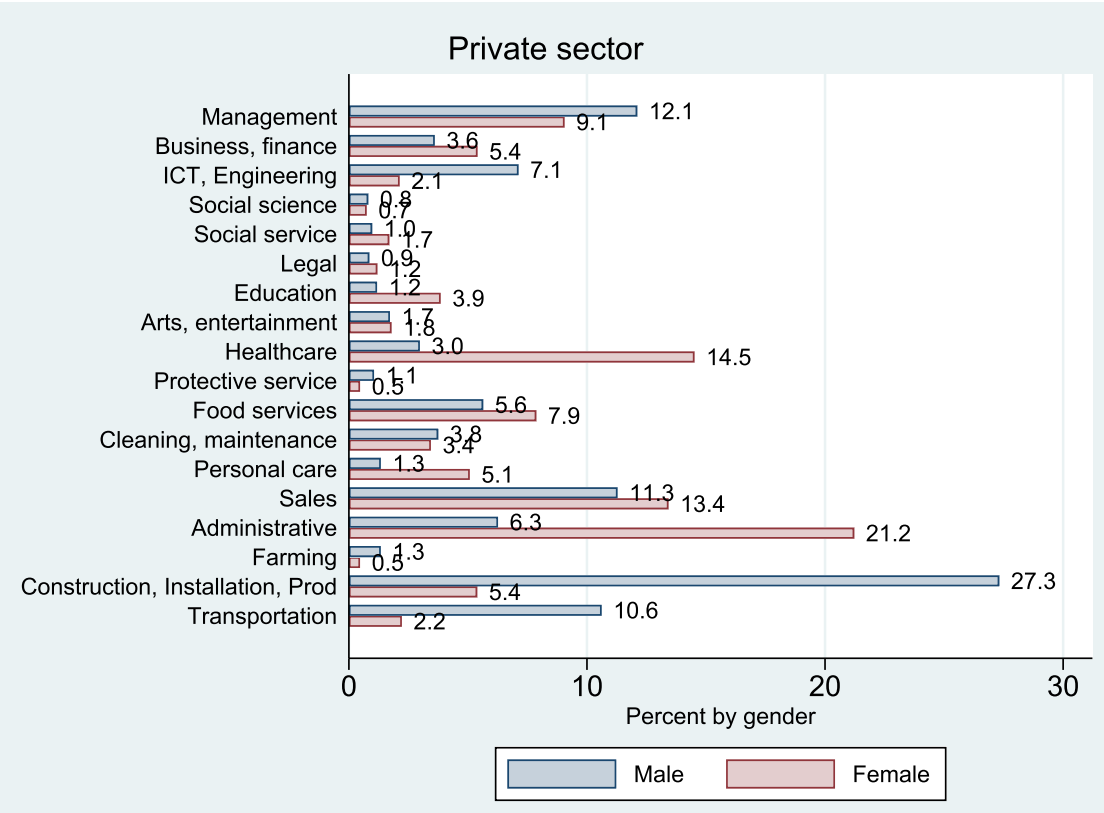

Fig. 16 Distribution of men and women across private sector occupations (averages for the period 20032019). Source CEPR-CPS, own calculations

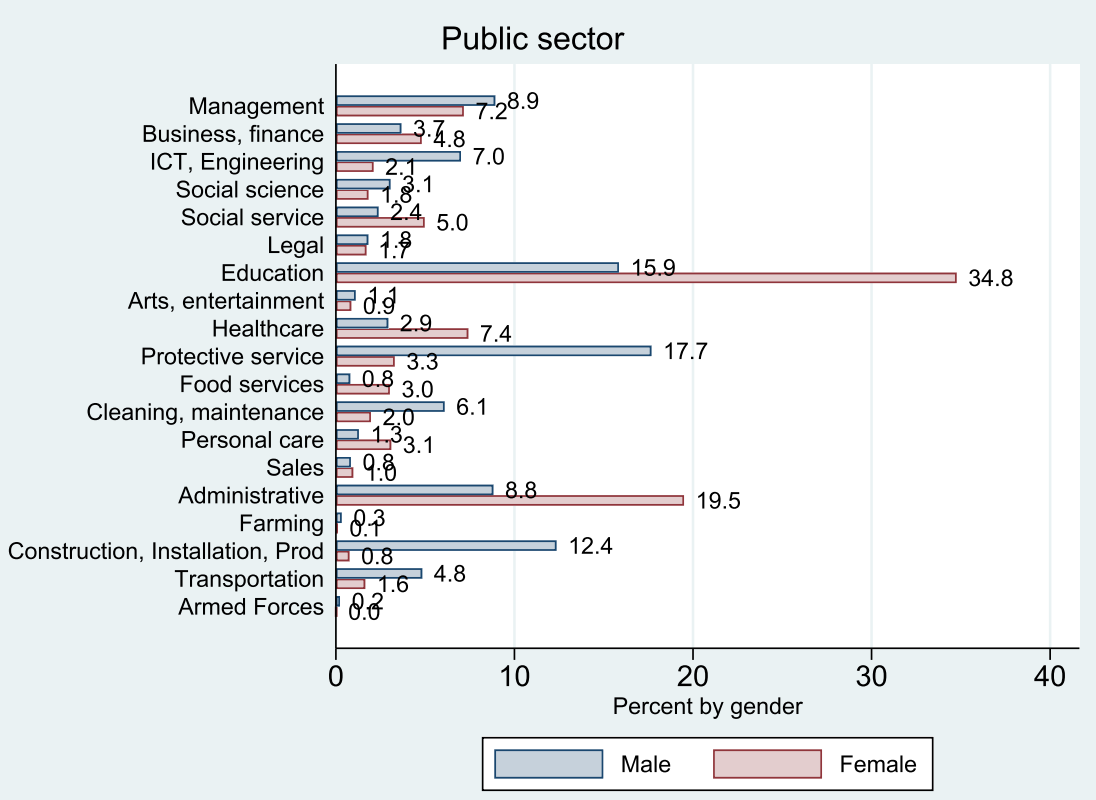

Fig. 17 Distribution of men and women across public sector occupations (averages for the period 20032019). Source CEPR-CPS, own calculations 


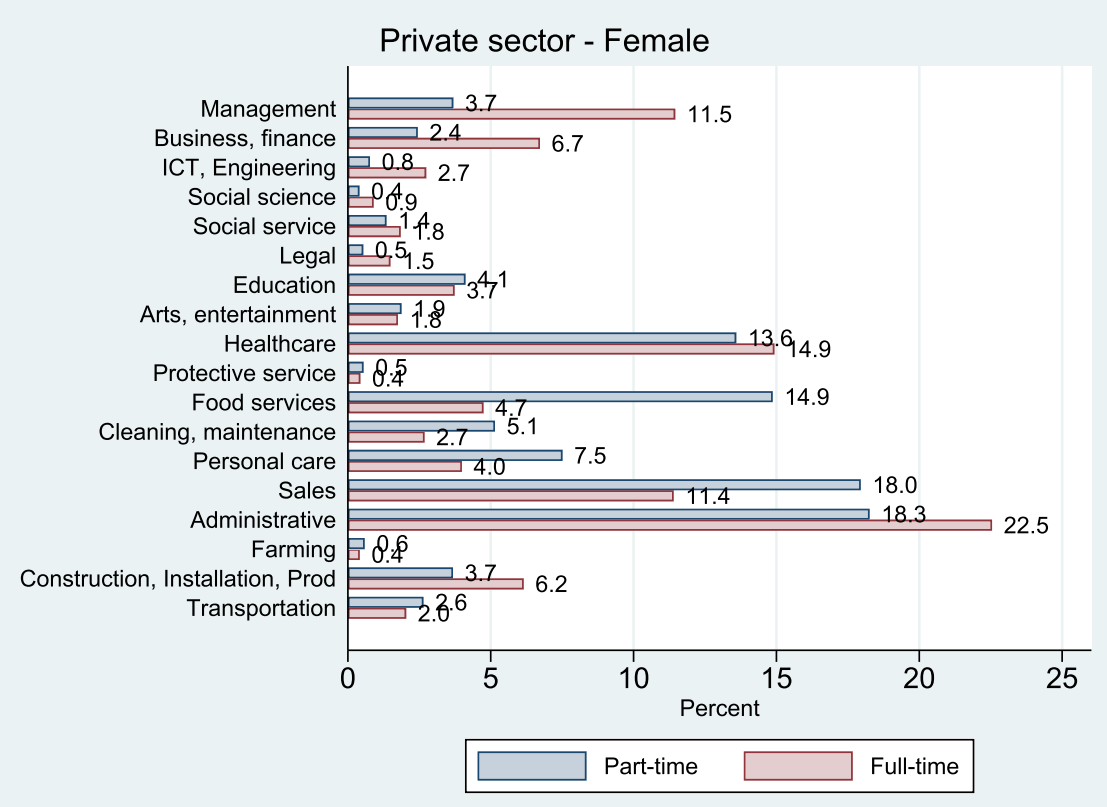

Fig. 18 Distribution of full- and part-time women across private sector occupations (averages for the period 2003-2019). Source CEPR-CPS, own calculations

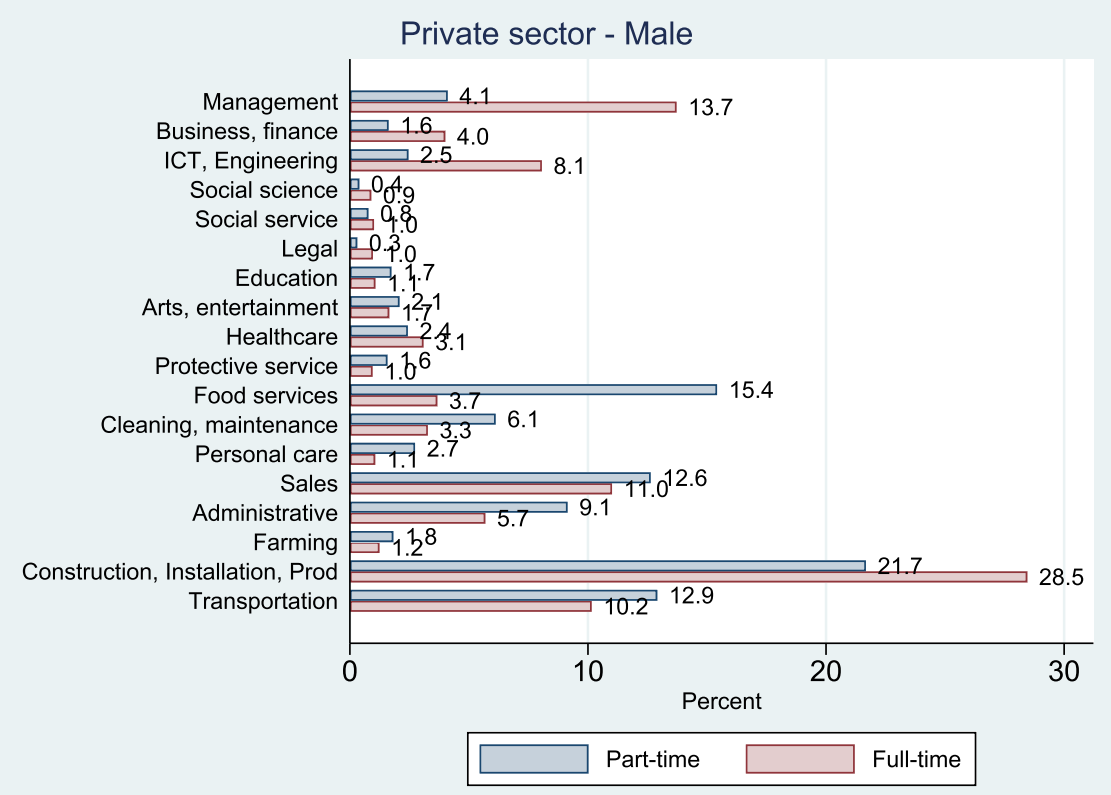

Fig. 19 Distribution of full- and part-time men across private sector occupations (averages for the period 2003-2019). Source CEPR-CPS, own calculations 


\section{VAR estimation method and algorithm for computing impulse response functions}

The procedure to identify the shocks follows the approach described in Arias et al. (2018) to make independent draws from the posterior distribution of structural parameters conditional on the sign and zero restrictions.

The VAR model can be written in the following general form:

$$
y_{t}^{\prime} A_{0}=\sum_{k=1}^{p} y_{t-k}^{\prime} A_{k}+c+\epsilon_{t}^{\prime}
$$

where $y_{t}$ is the vector of $n$ endogenous variables, $\epsilon_{t}$ a $n \times 1$ vector of exogenous structural shocks. The reduced form representation of this model is:

$$
y_{t}^{\prime}=x_{t}^{\prime} D+u_{t}^{\prime}
$$

where $D=B A_{0}^{-1}, u_{t}^{\prime}=\epsilon_{t}^{\prime} A_{0}^{-1}$ and $E\left(u_{t} u_{t}^{\prime}\right)=\Sigma=\left(A_{0} A_{0}^{\prime}\right)^{-1}$, and $B^{\prime}=$ $\left[A_{1}^{\prime} \ldots A_{p}^{\prime} c^{\prime}\right]$. The matrices $D$ and $\Sigma$ are the reduced-form parameters, $A_{0}$ and $B$ the structural parameters.

Let $h$ be any continuously differentiable mapping from the set of symmetric positive definite $n \times n$ matrices into the set of $n \times n$ matrices such that $h(X)^{\prime} h(X)=X$. In particular, $h(X)$ could be the Cholesky decomposition of $X$. We have $\left(A_{0}, B\right)=$ $\left(h(\Sigma)^{-1}, D h(\Sigma)^{-1}\right)$. We denote $f\left(h(\Sigma)^{-1}, D h(\Sigma)^{-1}\right)$ a function, with dimensions $n r \times n$, which stacks the impulse responses for the $r$ horizons where sign restrictions are imposed, such that it satisfies $f\left(h(\Sigma)^{-1} Q, D h(\Sigma)^{-1} Q\right)=f\left(h(\Sigma)^{-1}, D h(\Sigma)^{-1}\right) Q$ for any orthogonal matrix $Q \in O(n)$. Zero restrictions can be defined using matrices $Z_{j}$ of dimension $z_{j} \times n r$, with $z_{j}$ being the number of zero restrictions imposed on $f\left(h(\Sigma)^{-1}, D h(\Sigma)^{-1}\right)$. The parameters $(D, \Sigma)$ satisfy the zero restrictions if $Z_{j} f\left(h(\Sigma)^{-1} Q, D h(\Sigma)^{-1} Q\right) e_{j}=0$, for $1 \leq j \leq n$, where $e_{j}$ is the $j$ th column of the identity matrix $I_{n}$.

The main steps of the algorithm are the following:

1. Draw $(D, \Sigma)$ from the posterior distribution of the reduced-form parameters.

2. Draw $X=\left[x_{1}, \ldots, x_{n}\right]$ from an independent standard normal distribution.

3. Let $Q=\left[\frac{N_{1} N_{1}^{\prime} x_{1}}{\left\|N_{1}^{\prime} x_{1}\right\|} \cdots \frac{N_{n} N_{n}^{\prime} x_{n}}{\left\|N_{n}^{\prime} x_{n}\right\|}\right]$, where the columns of matrix $N_{j}$ form an orthonormal basis for the null space of the $\left(j-1+z_{j}\right) \times n$ matrix $M_{j}$ :

$M_{j}=\left[\frac{N_{1} N_{1}^{\prime} x_{1}}{\left\|N_{1}^{\prime} x_{1}\right\|} \ldots \frac{N_{j-1} N_{j-1}^{\prime} x_{j-1}}{\left\|N_{j-1}^{\prime} x_{j-1}\right\|} Z_{j} f(D, \Sigma)\right]$ for $1 \leq j \leq n_{s}$, where $n_{s}$ is the number of structural shocks considered.

4. Keep the draw if it satisfies all the sign restrictions.

5. Repeat steps 2-4 for $M$ draws of orthogonal matrices $Q$.

6. Repeat steps 1-5 for $N$ draws from the posterior distribution of the VAR parameters.

7. For all accepted draws, compute and save the corresponding impulse response.

8. Lastly, calculate the median, the 5 th, the 16 th, the 84 th and the 95 th percentiles of all the impulse responses. 


\section{E Data definitions and sources}

See Table 3.

Table 3 Data definitions and sources

\begin{tabular}{|c|c|c|}
\hline Variable & Source & Definition \\
\hline \multicolumn{3}{|c|}{ Government expenditures and receipts } \\
\hline Government investment & Bureau of Economic Analysis & $\begin{array}{l}\text { Gross government investment (Item } \\
\text { 3, Table 3.9.5) }\end{array}$ \\
\hline Government wage bill & Bureau of Economic Analysis & $\begin{array}{l}\text { Compensation of general government } \\
\text { employees (Item 4, Table } 3.10 .5 \text { ) }\end{array}$ \\
\hline $\begin{array}{l}\text { Government purchases of } \\
\text { private-sector goods and } \\
\text { services }\end{array}$ & Bureau of Economic Analysis & $\begin{array}{l}\text { Intermediate goods and services } \\
\text { purchased (Item 6, Table 3.10.5) }\end{array}$ \\
\hline Net tax revenue & Bureau of Economic Analysis & $\begin{array}{l}\text { Current tax receipts (Item 2, Table } \\
\text { 3.1.) plus Contributions for } \\
\text { government social insurance (Item 7) } \\
\text { plus Current transfer receipts } \\
\text { (Item 13) minus Current transfer } \\
\text { payments (Item 19) minus } \\
\text { Subsidies (Item 27) }\end{array}$ \\
\hline
\end{tabular}

Other macroeconomic variables

$\begin{array}{ll}\text { Total output } & \text { Bureau of Economic A } \\ \text { Interest rate } & \text { FRED } \\ \text { GDP deflator } & \text { Bureau of Economic A } \\ \text { Inflation rate } & \\ \text { Population } & \text { U.S. Bureau of Labor } \\ & \text { Statistics } \\ \text { Labor market variables } & \\ \text { Hourly wage } & \text { CEPR extracts of CPS } \\ & \text { MORG; Authors' } \\ & \text { calculations } \\ \text { Employment rate } & \text { CEPR extracts of CPS } \\ & \text { MORG; } \\ & \text { Authors' calculations }\end{array}$

Gross Domestic Product (Item 1, Table 1.1.5)

Federal Funds Rate (Item FEDFUNDS)

Prices Indexes for Gross Domestic Product (Item 1, Table 1.1.4)

Quarterly growth rate of GDP deflator

Civilian noninstitutional population (item LNU00000000)
Average real hourly wage of male (female) workers
Male (female) employment rate is constructed as the ratio of men
(women) employed to total male (female) working-age population

Table 3.1: Government Current Receipts and Expenditures; Table 3.9.5: Government Consumption Expenditures and Gross Investment; Table 3.10.5: Government Consumption Expenditures and General Government Gross Output 


\section{References}

Akitoby MB, Honda MJ, Miyamoto H (2019) Countercyclical fiscal policy and gender employment: evidence from the G-7 countries. IMF working paper series WP/19/4

Albanesi S, Şahin A (2018) The gender unemployment gap. Rev Econ Dyn 30:47-67

Alesina A, Ardagna S, Perotti R, Schiantarelli F (2002) Fiscal policy, profits, and investment. Am Econ Rev 92(3):571-589

Anderson E, Inoue A, Rossi B (2016) Heterogeneous consumers and fiscal policy shocks. J Money Credit Bank 48(8):1877-1888

Arias JE, Rubio-Ramírez JF, Waggoner DF (2018) Inference based on structural vector autoregressions identified with sign and zero restrictions: theory and applications. Econometrica 86(2):685-720

Bermperoglou D, Pappa E, Vella E (2017) The government wage bill and private activity. J Econ Dyn Control 79:21-47

Blau FD, Kahn LM (2000) Gender differences in pay. J Econ Perspect 14(4):75-99

Blau FD, Kahn LM (2013) Female labor supply: why is the United States falling behind? Am Econ Rev 103(3):251-56

Blau FD, Kahn LM (2017) The gender wage gap: extent, trends, and explanations. J Econ Lit 55(3):789-865

Bredemeier C, Juessen F, Winkler R (2017a) Fiscal policy and occupational employment dynamics. IZA discussion series (10466)

Bredemeier C, Juessen F, Winkler R (2017b) Man-cessions, fiscal policy, and the gender composition of employment. Econ Lett 158:73-76

Bredemeier C, Juessen F, Winkler R (2020) Fiscal policy and occupational employment dynamics. J Money Credit Bank 52(6):1527-1563

Clark KB, Summers LH (1981) Demographic differences in cyclical employment variation. J Hum Resour 16(1):61-79

Cogan JF (1981) Fixed costs and labor supply. Econometrica 49(4):945-963

Connelly R, Kimmel J (2003) Marital status and full-time/part-time work status in child care choices. Appl Econ 35(7):761-777

Cox L, Müller GJ, Pasten E, Schoenle R, Weber M (2020) Big G. NBER working paper (27034)

Deaton A (1985) Panel data from time-series of cross-sections. J Econometrics 30:109-126

Eckstein Z, Wolpin KI (1989) Dynamic labour force participation of married women and endogenous work experience. Rev Econ Stud 56(3):375-390

European Parliament (2015) Gender-responsive budgeting: innovative approaches to budgeting. Briefing, European Parliamentary Research Service

Fatás A, Summers LH (2018) The permanent effects of fiscal consolidations. J Int Econ 112:238-250

Finn MG (1998) Cyclical effects of government's employment and goods purchases. Int Econ Rev 635-657

Francesconi M (2002) A joint dynamic model of fertility and work of married women. J Law Econ 20(2):336-380

Giavazzi F, McMahon M (2012) The household effects of government spending. In: Fiscal policy after the financial crisis. University of Chicago Press, Chicago, pp 103-141

Gomes P, Kuehn Z (2019) You're the One that I Want! Public employment and women's labor market outcomes. IZA discussion papers, p 12702

Hamilton BH (2000) Does entrepreneurship pay? An empirical analysis of the returns to self-employment. J Polit Econ 108(3):604-631

Hoynes H, Miller DL, Schaller J (2012) Who suffers during recessions? J Econ Perspect 26(3):27-47

International Monetary Fund (2017) Gender budgeting in G7 countries. IMF policy papers

Kolberg JE (1991) The gender dimension of the welfare state. Int J Sociol 21:119-148

Misra K, Surico P (2014) Consumption, income changes, and heterogeneity: evidence from two fiscal stimulus programs. Am Econ J Macroecon 6(4):84-106

Mountford A, Uhlig H (2009) What are the effects of fiscal policy shocks? J Appl Economet 24(6):960-992

Nekarda CJ, Ramey VA (2011) Industry evidence on the effects of government spending. Am Econ J Macroecon 3(1):36-59

Ngai LR, Petrongolo B (2017) Gender gaps and the rise of the service economy. Am Econ J Macroecon 9(4):1-44

Olivetti C, Petrongolo B (2014) Gender gaps across countries and skills: demand, supply and the industry structure. Rev Econ Dyn 17(4):842-859

Pappa E (2009) The effects of fiscal shocks on employment and the real wage. Int Econ Rev 50(1):217-244 
Perugini C, Žarković Rakić J, Vladisavljević M (2019) Austerity and gender inequalities in Europe in times of crisis. Camb J Econ 43(3):733-767

Ramey VA (2011) Identifying government spending shocks: it's all in the timing. Q J Econ 126(1):1-50

Ramey VA (2013) Government spending and private activity. In: Alesina A, Giavazzi F (eds) Fiscal policy after the financial crisis. University of Chicago Press, Chicago, pp 19-55

Rudebusch GD (2006) Monetary policy inertia: fact or fiction? Int J Cent Bank 2(4):85-135

Saez E, Schoefer B, Seim D (2019) Hysteresis from employer subsidies. NBER working paper (26391)

Shin D (1999) An equilibrium theory of wage and employment cyclicality by gender and by industry. South Econ J 65(3):451-471

Solon G, Barsky R, Parker JA (1994) Measuring the cyclicality of real wages: how important is composition Bias? Q J Econ 109(1):1-25

Uhlig H (2005) What are the effects of monetary policy on output? Results from an agnostic identification procedure. J Monet Econ 52(2):381-419

van der Klaauw W (1996) Female labour supply and marital status decisions: a life-cycle model. Rev Econ Stud 63(2):199-235

Wall HJ, Engemann KM (2009) The effects of recessions across demographic groups. Federal Reserve Bank of St. Louis working paper series (2009-052A)

Publisher's Note Springer Nature remains neutral with regard to jurisdictional claims in published maps and institutional affiliations. 